http://dx.doi.org/10.12775/szhf.2018.057

\author{
KrzyszTOF KościuszKo \\ Uniwersytet Warmińsko-Mazurski, Olsztyn, Polska \\ ORCID: 0000-0003-4474-2885 \\ E-MAIL: LOISLOIS@INTERIA.PL
}

\title{
O nowym typie monadologii
}

Czy nie dałoby się rozszerzyć idei monadologicznej Witkacego? To znaczy czy nie można byłoby uznać, że materia martwa tylko pozornie jest martwa nie tylko dlatego, że da się zredukować do drobniejszego rzędu wielkości żywych monad, ale także dlatego, że m.in. podlega mechanizmom przysługującym materii żywej? O jakie mechanizmy by tu chodziło? Na przykład o mechanizm selekcji naturalnej opisanej przez Karola Darwina. Jeśli Wojciech Żurek opisuje zachowanie układów kwantowych w terminach darwinowskiej selekcji, to należałoby uznać, że te układy wykazują w pewnym sensie „życie”. Aby wyjaśnić brak kwantowych superpozycji w świecie makro, Żurek zakłada, że środowisko danego układu kwantowego eliminuje te stany, które nie są przystosowane, nie są stabilne ${ }^{1}$. Stany wyselekcjonowane jako zdolne do przetrwania $\mathrm{w}$ środowisku zostają rozmnożone, tj. występują $\mathrm{w}$ wielu identycznych kopiach. Kwantowy darwinizm Żurka (do którego czynimy tu jedynie aluzję) można potraktować jako jeden $\mathrm{z}$ argumentów na korzyść monadologii, inne argumenty można znaleźć m.in. we Wstępie do metafizyki S. I. Witkiewicza ${ }^{2}$. Jeśli materia "martwa” podlega tym samym mechani-

\footnotetext{
${ }^{1}$ Wojciech Żurek, “Quantum Darwinism”, Nature Physics 5 (2009): 181-188.

${ }^{2}$ Krzysztof Kościuszko, „Wstęp do metafizyki S. I. Witkiewicza”, Humanistyka i przyrodoznawstwo 22 (2016): 207-221.
} 
zmom, które rządzą materią „żywą”, tzn., że nie da się ustalić ścisłej granicy miedzy tym, co „martwe”, a tym, co „żywe”. Można by powiedzieć, że: jeśli biochemicy wyprowadzają materię „żywą" z materii „martwej”, to dlatego, że materia "martwa” pozornie tylko jest „martwa”; że w gruncie rzeczy jest już żywa - oczywiście chodzi tu o „żywość” w stanie potencjalnym. Życie może być pojęte jako produkt uboczny rozwoju „martwej” materii tylko wtedy, gdy materię "martwą" od razu wyposaży się we własności pre-biologiczne, ale istnienie takich własności odbiera przecież materii „martwej” jej martwotę.

Dlaczego mówię o innym rodzaju monadologii? Bo w jej perspektywie monady nie byłyby substancjami, lecz aktywnościami - aktywnościami organizującymi (integrująco-strukturującymi) albo dezorganizującymi, samymi aktywnościami. Aktywność integrująco-strukturująca jest tak ważna, bo nie ma jakiejkolwiek substancji, jakiejkolwiek cząstki, która istniałby bez wewnętrznej aktywności organizującej stabilność jej struktury³. Każda cząstka, będąc produktem jakiejś organizującej aktywności (jakiegoś zbioru monad), jednocześnie funkcjonuje organizująco na inne cząstki. Na przykład siły oddziaływań jądrowych silnych spajają kwarki w protony i neutrony, a wytworzone jądro (wraz z elektronami) jest podłożem aktywności sił elektromagnetyzmu wytwarzających atomy. Choć fizyka o tym explicite nie mówi, wszędzie w jej obszarze da się zaobserwować aktywność organizowania się (samoorganizowania się) struktur. Ten aspekt organizowania się proponuję nazwać aspektem monadycznym. Nawiązuję w ten sposób do niektórych (ale tylko niektórych) Leibnizjańskich określeń monady, opisujących ją jako formę substancjalną (siłę formującą). Jednakże mniejszy nacisk aniżeli w ujęciu Gottfrieda W. Leibniza kładłoby się w poniższej interpretacji na substancjalne podłoże aktywności, większy - na samą aktywność komponowania „jedności-w-wielości” (termin Witkacego). Według Leibniza monada nie jest samym działaniem, nie jest samą aktywnością, bo działanie miałoby według niego przysługiwać jedynie jakiejś określonej substancji duchowej i monada byłaby właśnie tą substancją. Natomiast w rozwijanej tutaj monadologii monada jest utożsamiona $\mathrm{z}$ samą aktywnością, ale niekoniecznie pojętą jako atrybut substancji duchowej. Dany typ aktywności powiązany jest $\mathrm{z}$ różnymi typami substancji - działanie monadyczne może wykazywać np. pole gra-

\footnotetext{
${ }^{3}$ Co jest pierwsze? Co jest arche? Aktywność organizująca czy organizowany materiał? Przecież ten materiał jest wytworem wcześniejszych aktów organizacyjnych. Czy z kolei akty organizujące mogą funkcjonować bez jakiegokolwiek materiału? Czy mogą działać w ontycznej pustce?
} 
witacyjne albo pole elektromagnetyczne, ale nie da się przecież nazwać tych pól „monadami” w znaczeniu Leibniza. Jeśli aktywność monadyczną mogą wykazywać przedmioty fizyczne, to takie ujęcie na pewno różni się też od ujęcia Witkacego, u którego monada pojęta jest jako substancja biologiczna.

Według Doyne’a Farmera w ewolucji wszechświata da się wyróżnić dwie tendencje: tendencję do wzrostu entropii oraz tendencję do stanów o coraz większym uporządkowaniu. Farmer chciałby „odnaleźć [...] uniwersalną siłę sprawczą, która nakazuje materii organizować się"4; uważa on, że wszechświat ma naturalną skłonność do porządkowania się. Z kolei Lynn Margulis przekonuje nas, że w świecie biologii działa „symbioza”, którą można uznać za coś w rodzaju monady. Oczywiście Margulis nie używa terminu „monada”, mówi ona raczej o aktywności symbiotycznej (chociaż też nie wprost), o symbiogenezie jako głównym mechanizmie powstawania nowych gatunków. Bez pojęcia symbiozy (czyli ujmując to w języku monadologii: bez pojęcia aktywności organizującej nowe struktury) samo pojęcie gatunku jest niezrozumiałe ${ }^{5}$. Bez procesów symbiozy nie wykształciłyby się jadra komórek, grzyby, rośliny i zwierzęta. Oto jak Margulis charakteryzuje symbiogenezę: „Za sprawą symbiogenezy dochodzi do łączenia niepodobnych i obcych sobie organizmów i powstawania nowych, większych i bardziej złożonych istot"6. Symbioza ,jest zjawiskiem naturalnym i powszechnym. Żyjemy w symbiotycznym świecie"”. Wyrażając to językiem monadologii, powiedzielibyśmy, że żyjemy w świecie aktywności monadycznej. Według Lynn Margulis to nie naturalna selekcja wyjaśnia ewolucję, lecz symbiogeneza (motyw antyneo-darwinowski).

W nowym typie monadologii trzeba by uwzględnić, że monady jako atomy życia, atomy negentropii (nie ma negentropii bez entropii i na odwrót; albo inaczej mówiąc: nie ma antymonad bez monad i na odwrót) organizują porządek w sposób deterministyczny i indeterministyczny zarazem. Czyli „życie" można by określić jako indeterministyczno-deterministyczny proces organizowania porządku (struktur). „Martwe” byłoby to, co zachowuje się w sposób czysto deterministyczny, ale czy taka martwota w ogóle istnieje?

\footnotetext{
${ }^{4}$ Doyne Farmer, „Druga zasada organizacji” w: Trzecia kultura, red. John Brockmann (Warszawa: CiS 1996), 507.

${ }^{5}$ Lynn Margulis, Symbiotyczna planeta, (Warszawa, CiS, 2000), 15.

${ }^{6}$ Ibidem, 18.

${ }^{7}$ Ibidem, 19.
} 
Modyfikacja monadologii Witkacego byłaby o tyle potrzebna, o ile - zgodnie z bardziej aktualnymi faktami nauki - trzeba by mocniej zaznaczyć, że przypadkowość występuje nie tylko na poziomie mikro. Powołując się na „prawo wielkich liczb” w wersji metafizycznej, Witkiewicz sądził, że deterministyczne zachowanie układów makro jest emergencyjnym rezultatem syntezy indetrministyczno-chaotycznych zachowań monad z poziomu mikro. Zakładał przy tym, że przypadkowe zachowanie przysługiwać może tylko organizmom żywym. Ale jak pokazała nauka współczesna (np. teoria chaosu deterministycznego), także układy makro mogą zachowywać się w sposób przypadkowo-chaotyczny. Na przykład w teorii deterministycznego chaosu zachowanie chaotycznych układów (zachowania układów fizycznych, klimatycznych, ekonomiczno-społecznych, biologicznych itd.) jest przewidywalne tylko w granicach określonego interwału czasowego, poza granicami którego zachowanie tych układów staje się przypadkowe. Czyżby ta makroprzypadkowość i ten makrochaos były rezultatem działania mikromonad?

U Witkacego wszystko, co fizyczne, zachowuje się (względnie powinno się zachowywać) w sposób deterministyczny. Pod deterministyczno-fizycznym pozorem miałaby się ukrywać prawdziwa rzeczywistość monadyczno-indeterministyczna. Wynikać by to miało z prawa wielkich liczb, które m.in. głosi, że przypadkowe zachowanie izolowanych mikrocząstek ustępuje miejsca ich zachowaniu deterministycznemu, kiedy tylko przestaną one być od siebie odseparowane, tj. kiedy wystąpią w grupie. Podążając za tokiem myślenia Witkacego, trudno byłoby uznać indeterministyczne zachowanie rzeczywistości fizycznej w wymiarach makro za efekt działania mikromonad. Jeśli indeterministyczne działanie makroukładów uznać (zgodnie z logiką Witkacego) za przejaw „życia” (bo „żywe” jest m.in. to, co zachowuje się w sposób indeterministyczny), to ten makroprzejaw kłóciłby się przecież z akceptowanym przez autora Zagadnienia psychofizycznego prawem wielkich liczb. Może więc zmienić definicję życia? Według Witkacego mikroindeterminizm mikromonad nie udziela się makrodeterminizmowi, zostaje on na poziomie makro wygaszony, a wraz z wygaśnięciem mikroindeterminizmu miałaby wygasać obecność biologicznego życia w świecie fizycznym, ale przecież nauka współczesna uobecniła nam istnienie indeterministyczno-chaotycznych zachowań układów fizycznych także na poziomie makro (w reżimie nieliniowym), a to świadczyłoby o tym, że także poziom makro jest poziomem „życia”. Trzeba by więc rozszerzyć monadologię o pojęcie makromonadyzmu i makroindeterminizmu. Aktywność organizowania, względnie dezorganizowania porządku występuje na każdym poziomie: mikro, makro i mega, i może przebiegać 
w sposób deterministyczny, indeterministyczny i deterministyczno-indeterministyczny. Fizykalny makroporządek może się budować z mikrochaosu (tak jest u Witkacego), ale pamiętajmy, że ten porządek na poziomie makro wcale nie jest czymś stabilnym i że przyczyny jego zamienienia się w makrochaos wcale nie muszą tkwić w świecie mikro. Witkacy filozofował w takim paradygmacie, w którym to, co fizyczne, było domeną porządku i determinizmu (krytykował on np. obiektywistyczne interpretacje kwantowego indeterminizmu). W nowym typie monadologii powinno się uwzględnić fakt, że nie tylko biologicznym mikroskładnikom „materii martwej” przysługuje przypadkowość (tak jest w monadologii Witkacego); że przejście od chaosu do porządku nie jest powiązane tylko i wyłącznie z przejściem ze sfery biologii do sfery fizyki. Jeśli więc materia „martwa” jedynie pozornie jest „martwa", to nie tylko dlatego, że miałaby się składać z biologicznych atomów (witkiewiczowskich monad), ale także dlatego, że w skali makro zachowuje się na podobieństwo organizmów żywych, tj. dlatego, że obecne są w niej procesy samoorganizacji (procesy organizowania i dezorganizowania struktur) dokonujące się w sposób deterministyczno-indeterministyczny. Według Witkacego fizykalne determinizmy są emergentnym rezultatem zbiorowych oddziaływań zwrotnych zachodzących między biologicznymi mikromonadami, ale witkiewiczowska wizja wyklucza możliwość indeterministycznego zachowania się fizycznego wszechświata w całości albo jakichś jego mega albo makro składników. Wyklucza też możliwość przejścia fizycznego makro- czy megachaosu w fizyczny makro- czy megaporządek. Zjawisko makronieliniowości powinno znaleźć odzwierciedlenie w monadologii. Wraz z odkryciami teorii deterministycznego chaosu nieliniowość - przysługująca materii żywej - została odnaleziona w materii martwej, a więc także materia martwa powinna być uznana za „żywą”. Materia martwa jest „żywa”, bo (poza innymi cechami przysługującymi materii żywej) w skali makro zachowuje się w sposób nieliniowy, tj. w dłuższym okresie ewoluuje w sposób przypadkowy, nieprzewidywalny (jakby posiadała wolną wolę). Czy nieprzewidywalność wyklucza przewidywalność? Raczej nie! Nieprzewidywalność przechodzi w przewidywalność i na odwrót. $\mathrm{W}$ reżimie nieliniowym to, co stabilne, pojawia się wewnątrz niestabilności; to, co periodyczne, koegzystuje z chaosem - tego nauczyła nas teoria deterministycznego chaosu. Współczesna monadologia mogłaby się nazywać monadologią fizykalno-biologiczną (a nie monadologią biologiczną - jak u Witkacego), bo sama fizyczna przedmiotowość - bez sięgania w głąb, do poziomu mikro wykazuje cechy przedmiotowości biologicznej, tj. jej nieliniowość. Przedmioty fizyczne podlegają 
deterministyczno-indeterministycznej aktywności organizującej, działającej w nich i między nimi.

Czy monady są otwarte czy zamknięte? Z termodynamicznego punktu widzenia w układach zamkniętych wzrasta entropia, tj. mówiąc językiem monadologii: wzrasta aktywność antymonadyczna, aktywność chaotyzująca; ale zamkniętość zawsze można otworzyć na działanie aktywności strukturyzującej porządek. Wszechświat istnieje w stanie nierównowagi: gorące gwiazdy jako ośrodki aktywności monadycznej bez przerwy oddziałują na zimniejsze obszary przestrzeni kosmicznej, na materię zawartą $\mathrm{w}$ tych obszarach, materię otwartą na dopływ energii z zewnątrz. W układach otwartych przyrosty porządku dokonują się kosztem skorelowanych przyrostów chaosu. W naszym Wszechświecie jako całości mamy splątanie zamkniętości z otwartością; w pewnych jego zakątkach rośnie porządek, choć w perspektywie całościowej zbliżamy się do cieplnej śmierci. Nie da się odizolować aktywności chaotyzującej od aktywności organizującej porządek; nie da się odseparować antymonad od monad. Monady uruchamiające porządek są otwarte na działanie antymonad uruchamiających chaos. Ale także monady kreujące porządek nie egzystują w stanie izolacji od siebie; są one otwarte na oddziaływania wzajemne. Jeśli np. rozpatrzeć relację Ziemi do Słońca, to jest oczywistością, że Słońce jako źródło aktywności organizująco-strukturującej permanentnie przyczynia się do powstania układów uporządkowanych na kuli Ziemskiej, w tym do powstania życia biologicznego. Organizmy żywe nie wykształciłyby się bez aktywności słonecznej, ale nie wykształciłyby się też bez aktywności całej biosfery - do ich powstania przyczynił się więc cały kompleks różnych aktywności współdziałających i oddziałujących na siebie nawzajem.

Aktywność organizująca przejawia się w zachowaniach celowych. Co to są zachowania celowe? Są to takie zachowania, których aktualnego przebiegu nie da się wytłumaczyć w oparciu o czynniki zaistniałe tylko i wyłącznie w przeszłości. Trzeba się odwołać do czynników (stanów, procesów, struktur itd.), które zaistnieją dopiero w przyszłości. Teraźniejszość tłumaczymy tutaj przez odwołanie się do atraktora, czyli punktu, w który nakierowana jest strzałka czasu. Logika zdarzeń teraźniejszych nie da się ująć jako wynika- 
jąca jedynie ze zdarzeń przeszłych, bo w samej teraźniejszości odnajdujemy obiektywną tendencję, nakierowanie na przyszłą sytuację i dostosowanie się do niej. Ciekawym tego przykładem w obszarze fizyki może być eksperyment Scully’ego ${ }^{8}$, w którym fizyczne cząstki (np. fotony) dostosowują swoje zachowanie do oczekującego je zetknięcia z polaryzatorami. Tak jakby cząstki uświadamiały sobie z góry, co je czeka w przyszłości. „Celowość” ich zachowania polega na dokonującym się w teraźniejszości dostosowaniu do przyszłości, „uwzględnieniu” tego, co dopiero się wydarzy.

Oczywiście to ukierunkowanie szeregu wydarzeń, ukierunkowanie zgodne ze strzałką czasu, nie musi być świadomym rezultatem jakichś podmiotowych przemyśleń. Obecność obiektywnego celu rozpoznajemy po ukierunkowanych zmianach zachodzących w realnym świecie, po ukierunkowanej ewolucji, np. w sterowanej genetyczną informacją ewolucji fenotypu danego organizmu. Nie znaczy to, że dany cel jest łatwo rozszyfrować i że w ogóle go odczytamy. Skąd wiemy, że ewolucja wszechświata jest ukierunkowana? Zgodnie z drugą zasadą termodynamiki wiemy np., że ewolucja zamkniętych układów nakierowana jest na osiągnięcie stanu równowagi. W przypadku wszechświata osiągnięcie stanu termodynamicznej równowagi będzie równoważne $\mathrm{z}$ „cieplną śmiercią”, ponieważ żadne ze źródeł kosmicznej energii nie zdoła ogrzać przestrzeni Wszechświata. Strzałka czasu jest wycelowana w powiększenie chaosu. Oczywiście możliwa jest, choć bardzo mało prawdopodobna, ewolucja odwrotna - od chaosu do porządku, ale w perspektywie teleologicznej nie chodzi nam o to, jaki konkretny kierunek z jakim prawdopodobieństwem będzie miała kosmologiczna strzałka czasu, tylko o to, że w ogóle w ewolucji kosmicznej da się wyróżnić jakiś kierunek (jakiś cel, jakiś atraktor). Podobnie ewolucja układu Słońce-Ziemia zmierza od stanu o niskiej entropii do stanu o wysokiej entropii. Dzięki różnicy temperatur na kuli ziemskiej mogą powstawać rozmaite struktury uporządkowane, jednak kosmiczna strzałka czasu, wycelowana w zagaśnięcie Słońca, powodować będzie obumieranie porządku, tj. zwiększenie aktywności antymonadycznej (chaotyzującej). Cóż nam mówi teoria chaotycznej inflacji? W modelu chaotycznej inflacji Lindego na początku (początku kwantowym) ewolucji Wszechświata panuje chaos. Wszechświat ustrukturyzował się z cząstek powstałych w przypadkowych kwantowych fluktuacjach próżni. A ponieważ występuje druga zasada termodynamiki w każdym układzie fizycznym, więc

${ }^{8}$ Paul Davies, Czas. Niedokończona rewolucja Einsteina (Warszawa, Prószyński i S-ka, 2006), 190. 
fazy uporządkowane kosmicznej ewolucji ustąpią miejsca fazom chaotycznym. Z kolei chaos może znowu ustąpić miejsca porządkowi. Nastąpi to wtedy, gdy dany podukład danego wszechświata albo jakiś jeden $\mathrm{z}$ wszechświatów multiświata otworzy się na organizujące odziaływanie innego podukładu albo monadyczne działanie innego wszechświata. Wtedy zmieni się strzałka czasu wycelowana w powiększanie chaosu.

$\mathrm{Z}$ działaniem teleologicznym mamy do czynienia wtedy, gdy działanie cząstkowe jakiegoś układu jest uwarunkowane sytuacją całościową, działaniem całościowym. Całość układu i warunki jego stabilności (względnie przetrwania) są tu czymś pierwotnym (i czasowo wyprzedzającym) w stosunku do aktywności składników układu. „Celowymi” mechanizmami i siłami będą takie, które albo utrzymują trwałą organizację układu albo jego trwałe własności, albo trwałe czynności. Tego typu definicje stosują się zarówno do układów fizycznych, jak i do układów biologicznych. Weźmy np. jądro atomowe, które jest przecież zorganizowane na sposób trwały. Jeśli powiemy, że ta stabilność jądra jest celowo zorganizowana przez siły oddziaływania jądrowego silnego, brzmi to - w perspektywie rozumienia celowości jako aktów dokonywanych przez świadomą podmiotowość - jak absurd. Czyżby te siły działały w sposób świadomy? Czyżby one chciały istnienia tej stabilności? Czyżby to był świadomy cel ich działań? Wykluczone! Z niczym takim nie mamy tu do czynienia. Ale ponieważ używamy pojęcia celowości w zupełnie swoistym znaczeniu i „celową” nazwiemy nieuświadamianą i niechcianą aktywność (aktywność czysto fizyczną) przyczyniającą do organizowania stabilności jądra, więc jeśli weźmiemy pod uwagę, że aktywność oddziaływań jądrowych silnych spełnia taką właśnie funkcję (choć w sposób nieświadomy i nieuświadamiany), to nazwanie tej aktywności aktywnością „celową” wcale nie musi wydawać się czymś absurdalnym. Przez działanie celowe w obszarze świata fizyki rozumiemy m.in. nieświadome (niepodmiotowe) działanie podtrzymujące jakiś trwały stan całego układu pomimo zmian środowiska.

Jeśli materia martwa pozornie tylko jest martwa, to głównie dlatego, że jest otwarta na zmiany; że jej przyszłość nie jest zawarta w przeszłości; że nie jest mechanizmem powtarzającym „to samo”. Z monadologicznego punktu widzenia oznacza to, że fazy uporządkowane jakiegoś procesu, następujące po fazach chaotycznych, nie są wiecznotrwałe. Nakierowania na budowanie chwilowych porządków, ustępuje miejsca nakierowaniu na chwilowe fazy chaosu i na odwrót. Monady organizujące porządek (względnie chaos) nie muszą organizować wciąż tego samego porządku, mogą one organizować nowe porządki i nowe struktury. Jeśli dany proces jest dynamiczno-twórczy, 
to znaczy, że w trakcie jego zachodzenia uruchamiają się rozmaite monady i antymonady w rozmaitej kolejności i proporcji. Monady są różne - i to stwierdzenie jest zgodne $\mathrm{z}$ tezami monadologii Leibniza, $\mathrm{u}$ którego monady są jakościowo zróżnicowane, stanowią indywidualności. Co to jednak znaczy $\mathrm{w}$ perspektywie prezentowanej monadologii, że monady są różne? To znaczy, że różne są aktywności organizujące rozmaite struktury przedmiotowe. Ponieważ sfera przedmiotowości różnicuje się permanentnie, więc jest to sygnał, że także konstytuująca ją aktywność musi się różnicować. Różnicujące się układy fizyczne, chemiczne, biologiczne i inne stanowią zewnętrzny, czyli cielesny przejaw wewnętrznej aktywności monadycznej (albo antymonadycznej). Fizyczna czy chemiczna „cielesność” jest zewnętrzną postacią wewnętrznej, niecielesnej aktywności monadycznej; jest zewnętrzną ekspresją wewnętrznej aktywności organizującej - tak można by zinterpretować tezę Leibniza, według której monada nie jest ciałem, choć na zewnątrz prezentuje się jako ciało. Monada transcenduje cielesność (swą zewnętrzną ekspresję) i dlatego m.in. nazywa się punktem metafizycznym, a nie fizycznym. To, co fizyczne, dotyczy zewnętrznych przejawów aktywności organizującej, a nie samej aktywności, która jest cieleśnie - w sposób bezpośredni - nieuchwytna. O tak pojętej monadzie Leibniz powiedziałby, że jest „nierozciągła”. Rozciągłe są tylko jej zewnętrzne ekspresje.

Na leibnizjańskie pytanie: „dlaczego jest raczej coś, a nie nic” można by odpowiedzieć (i jest to jedna $\mathrm{z}$ możliwych odpowiedzi) następująco: materia pojawiła się z kwantowej próżni („nicości”), która wcale nie była próżna, bo były w niej cząstki wirtualne. W tej próżni pojawiały się kwantowe fluktuacje, w wyniku działania których wytworzyły się bąble czasoprzestrzeni, rozdęte następnie do ogromnych rozmiarów. Materia jest rezultatem monadycznej pracy energii ciepła i energii grawitacyjnej. A więc coś powstało z „nicości”, która wcale nie była nicością. „Coś” powstało z „czegos””.

W jakim sensie finalizm dopełnia mechanicyzm? Chodzi o to, że maszyneria zjawisk ma strzałkę czasu. Oczywiście, że maszyneria jest czymś bezpośrednio obserwowalnym, natomiast odgadywanie kierunku mechanicznych zmian przekracza bezpośrednio dane, ale to nie znaczy, że pojęcie celu jest 
w ogóle zbędne. Otóż pojęcie celu pozwala uporządkować następstwo zmian, odnaleźć wśród nich jakiś porządek, przewidzieć przyszły scenariusz rozwoju zdarzeń. Na przykład w badaniach kosmologicznych poprzez badanie mechanicznych zależności między grawitacją a tempem ekspansji kosmicznej czasoprzestrzeni można odgadnąć kierunek zmian ewolucji wszechświata (atraktor), co pozwala na uporządkowanie zarówno danych dotyczących początku tej ewolucji, jak i kolejnych jej faz (które nie są bezpośrednio obserwowalne). Jeśli grawitacja wstrzyma przyrosty rozmiarów Wszechświata, atraktorem kosmicznych przemian będzie „wielki skurcz”, zamiana cząstek $\mathrm{w}$ energię, unicestwienie czasoprzestrzeni i rozpłynięcie się wszystkiego w próżni.

Teleologia uzupełnia mechanicyzm w tym sensie, że o ile w myśleniu mechanistycznym zachowanie się całego układu jest pojęte jako rezultat aktywności składników, o tyle w myśleniu teleologicznym na odwrót - to poprzez odwołanie się do zachowania się całego układu interpretujemy aktywność jego składników. Mamy tu oddziaływanie zwrotne części na całość: kiedy interpretujemy teleologicznie, interpretujemy zachowanie części poprzez zachowanie się większej całości; natomiast kiedy interpretujemy mechanistycznie, ujmujemy całość jako uzależnioną od działania swych składników.

Co oznacza „harmonia z góry (wprzód) ustanowiona”? Oznacza zgranie się poszczególnych monad (aktywności integrująco-strukturujących) - takie zgranie, które gwarantuje poprawne funkcjonowanie (tj. np. funkcjonowanie utrzymujące homeostazę albo trwałe własności danego układu) danej struktury fizykochemicznej czy biologicznej. Jeśli struktury mają charakter dynamiczny, wtedy „harmonia” będzie takim zestrojeniem monad, w którym uruchamianie się kolejnych monad gwarantować będzie wykształcenie się danej struktury, tak jak to zachodzi np. w przypadku uruchamiania się kolejnych aktów organizacyjnych kolejnych genów sterujących rozwojem danego osobnika. Czasem zestrojenie dokonuje się ze względu na cel, którym może być genetyczne wykodowanie jakiegoś biologicznego organu albo zniszczenie wirusa, ale $\mathrm{z}$ harmonią mamy do czynienia także $\mathrm{w}$ przypadku struktur kosmicznych. Przykładem może być wyrażone w zasadzie antropicznej harmonijne zestrojenie się różnych wartości wielkości fizycznych i kosmologicznych, zestrojenie umożliwiające powstanie biologicznego życia. Mówiąc językiem monadologii, powiedzielibyśmy, że zestrojenie tych wartości 
uruchamia zadziałanie monad sterujących powstaniem biologicznego życia. Samo zestrojenie może być dziełem przypadku. Z kolei samo biologiczne życie działa harmonijnie (jak głosi hipoteza Gai) poprzez samoregulację, np. poprzez planetarną termoregulację (która jest jeszcze innym przykładem monadyzmu). Jeśli występuje tu teleologia, to nie ma ona nic wspólnego z jakąś świadomą i planowo działającą podmiotowością: „Gaja nie potrzebuje świadomości, by reagować na zmiany ziemskiego środowiska”10 (zarazem planetarną regulację temperatury da się pogodzić z obowiązywalnością praw doboru naturalnego) ${ }^{11}$.

Wszechświat jest przyjazny biologicznemu życiu nie dlatego, że istnieje jakiś „plan” stworzenia, jakiś zamierzony cel istnienia fizykalnej materii, a celem tym miałoby być jakoby wyklucie się życia. Otóż można uniknąć tego typu teleologii (choć nie da się uniknąć innego typu teleologii), zachowując jednocześnie ideę wszechświata przyjaznego życiu. Wszechświat jest przyjazny życiu, bo od samego początku (powiedzmy od Wielkiego Wybuchu) jest życiem (negentropią), czyli jest samoorganizacją, aktywnością organizującą struktury od najbardziej prostych do najbardziej złożonych. Nie dlatego biologiczne życie nie jest dziełem tylko i wyłącznie przypadku, że miałoby być dziełem transcendentnej teleologii, ale dlatego, że cała kosmiczno-fizyczna materia pozornie tylko jest martwa. $\mathrm{W}$ istocie zbudowana jest ona $\mathrm{z}$ monad.

Zupełnie przypadkowa geneza biologicznego życia we wszechświecie jest nieskończenie mało prawdopodobna, ale czy hipoteza akceptująca interwencję transcendentnego planu jest bardziej prawdopodobna? Wstrzymywanie się od powoływania się na teleologię transcendentną nie oznacza, że musimy odrzucić teleologię w ogóle. Przecież nie da się zanegować, że dyskurs teleologii immanentnej jest dyskursem sensownym. Co oznacza immanentna teleologia? Oznacza np. to, że istoty żywe nie są maszynami; że do wyjaśnienia ich miniczynności trzeba odwołać się do organizacji, do struktury całościowej i całościowych funkcji. Trzeba też uwzględnić rozmaite poziomy danej struktury i ich hierarchię i nie przeoczyć ukierunkowania procesów (strzałki czasu); wziąć też pod uwagę homeostazę. Albo kiedy mówimy, że naturalna

\footnotetext{
${ }^{9}$ Margulis, Symbiotyczna, 158-182.

${ }^{10}$ Ibidem, 178.

${ }^{11}$ Ibidem, 180.
} 
selekcja eliminuje organizmy słabiej przystosowane i nagradza lepiej przystosowane i że poprzez to napędza ewolucję w kierunku lepszego przystosowania organizmów i populacji, pozostajemy w ramach teleologii immanentnej.

Według monadologii zaistnienia życia $\mathrm{w}$ kosmosie $\mathrm{w}$ ogóle nie powinno się pojmować jako emergencji tego, co „żywe”, z „martwego” (nieorganicznego) materiału fizyczno-chemicznego, ale jako powstanie życia bardziej zaawansowanego (skomplikowanego) z życia bardziej prymitywnego, inaczej: jako powstanie monadyzmu bardziej skomplikowanego z monadyzmu mniej skomplikowanego. Biologiczne życie - ujęte w optyce abiogennej jest przejawem materii fizyczno-chemicznej, ale ujmując rzecz metafizycznie, można by powiedzieć, że abiogenne teorie powstania życia na Ziemi tylko dlatego są możliwe, że sama fizykochemiczna materia jest w gruncie rzeczy przepojona życiem: i od wewnątrz (bo to, co martwe, zbudowane jest z monad) i od zewnątrz (bo pozornie "martwa” materia zachowuje się jak „żywa”). Według jednej z hipotez biologiczne życie miałoby być wytworem syntezy kwasów nukleinowych $\mathrm{z}$ aminokwasami, ale $\mathrm{z}$ monadologicznego punktu widzenia również same te kwasy rozpatrywane w izolacji od siebie są ekspresjami „życia”, tj. aktywności monadycznej. I nie tylko te kwasy, ale także budujące je cząsteczki i atomy (jako względnie stabilne struktury istniejące dzięki aktywności wytwarzające tę stabilność). Wszystkie formy życia (i te biologiczne, i te fizykochemiczne) różnią się od siebie, a zarazem wszystkie one są tożsame. Biologiczne życie wirusa czy bakterii jest inne niż życie kwasów nukleinowych, a to ostatnie różni się od życia atomów węgla, ale wszystkie te formy są przejawami różnych gatunków aktywności organizującej. Prezentowana tu monadologia ma do pewnego stopnia oparcie w teorii Ilyi Prigogine'a i Stuarta Kauffmana. Kauffman ujmuje biologiczne życie w perspektywie zasad samoorganizacji działającej zarówno w układach prostych (pozornie nieożywionych), jak i w coraz bardziej złożonych, przejawiających cechy organizmów żywych. Pojawienie się biologicznego życia byłoby poprzedzone zadziałaniem chemicznych sieci i cyklów autokatalitycznych wykazujących aktywność organizującą, np. katalizatory działające w pierwotnej zupie oceanicznej mogły katalizować swą własną produkcję. Jeszcze przed pojawieniem się jednokomórkowców samoorganizacja chemicznych sieci (a więc w obrębie materii fizyczno-chemicznej) prowadzi do wykształtowania się czegoś w rodzaju metabolizmu i coraz większej złożoności przed-biologicznej. W wizji Kauffmana biologiczne życie okazuje się produktem szeregu procesów samoorganizowania się. Sugeruję więc, że 1) jeśli procesy organizowania się materii (samoorganizowania) można zinter- 
pretować jako pierwotne względem samego biologicznego życia, 2) jeśli procesy samoorganizacji produkują biologiczne życie, to znaczy, że ta możliwość jest potencjalnie $\mathrm{w}$ nich zawarta; że więc one same są w jakimś sensie życiem (bo - metafizycznie rzecz ujmując - życie może powstać tylko z życia), 3) „życie” można by więc określić znacznie szerzej aniżeli jest ono określone potocznie jako związane tylko i wyłącznie z biologicznymi jego formami, a mianowicie jako procesy organizowania się materii, wszystko jedno jakiej: fizyczno-chemicznej czy stricte biologicznej. W ten sposób dochodzimy do "monady” pojętej jako aktywność organizowania się. Podobnie do Kauffmana Prigogine wykazał, że zarówno w chemicznych mieszaninach, jak i w biologicznych organizmach można zaobserwować te same procesy samoorganizacji. Aktywność organizowania jest ta sama, ale zarazem jest odmienna, bo do zorganizowania rozmaitych struktur fizyczno-chemicznych potrzebne są inne zbiory monad niż do zorganizowania struktur stricte biologicznych. W punktach bifurkacji monady budujące dane struktury albo ustępują miejsca monadom budującym wyższe poziomy organizacji, albo zostają zastąpione antymonadami, czyli aktywnościami dezorganizującymi (prowadzącymi do uchaotycznienia danej struktury).

W prezentowanej w artykule monadologii wszystko jest przejawem życia, czyli monadyzmu (aktywności organizującej albo dezorganizującej) - mamy więc monizm, ale mamy też pluralizm, bo każda struktura jest wytworem różnej kombinacji monad. Jasne, że poszczególne monady różnią się od siebie, ale różnią się też odmianą kombinacji, w które wchodzą. Wszystko jest zbudowane $\mathrm{z}$ monad, ale monady nie są pojęte jako substancje duchowe (tak jest u Leibniza) albo biologiczne (tak jest u Stanisława I. Witkiewicza). Są one zinterpretowane jako aktywność organizująca. Skąd ten zwrot w kierunku organizowania (samoorganizowania)? Jest on m.in. (poza czynnikami omówionymi wcześniej) odpowiedzią na tezy teorii informacji, według której pojęcie informacji stopniowo wypiera pojęcie materii. Informacja (np. genetyczna) pojęta jako negentropia odgrywa podstawową rolę w organizowaniu funkcjonujących struktur. Jeśli ująć biologiczne życie jako proces przetwarzania informacji, to byłoby to możliwe dzięki monadom, tj. aktywności organizującej (i przeorganizowującej) dane struktury, aktywności wytwarzanej chociażby w zjawisku rekombinacji genów. Jeśli procesy przetwarzania informacji zaczęły się od początku zaistnienia wszechświata, to byłoby 
to możliwe dzięki całej serii aktywności organizujących i przetwarzających dane wyjściowe $\mathrm{w}$ jakieś coraz to nowe struktury, których oddziaływanie wzajemne może stanowić motor wyzwalania się coraz nowych monad. Jeśli zaakceptować tezę o obliczeniowym charakterze wszechświata (wszechświat oblicza), tj. jeśli każda wytworzona kosmiczna struktura jest $\mathrm{z}$ jednej strony przetworzoną informacją, a $\mathrm{z}$ drugiej informacją przetwarzającą, to monizm monadologiczny byłby wzmocniony, bo przecież samo przetwarzanie informacji można ująć jako pewną postać aktywności organizującej. Czy przetwarzanie kosmicznej informacji ma jakiś cel? Czyż ewolucja tej informacji nie jest nakierowana na śmierć cieplną wszechświata? Ale jeśli istnieje wielość wszechświatów, to śmierć jednego z wszechświatów nie musi oznaczać śmierci innych. Życie byłoby wieczne.

\section{Bibliografia}

Davies Paul. 2002. Czas. Niedokończona rewolucja Einsteina. Warszawa: Prószyński i S-ka, Farmer Doyne. 1996.

Farmer J. Doyne. 1996. Druga zasada organizacji. W: Trzecia kultura, red. John Brockman. Warszawa: CiS, 495-518.

Kościuszko Krzysztof. 2004. Nowa formuła monadologii. Olsztyn: Wydawnictwo UWM.

Kościuszko Krzysztof. 2016. „Wstęp do metafizyki S. I. Witkiewicza”. Humanistyka i przyrodoznawstwo 22: 207-221.

Margulis Lynn. 2000. Symbiotyczna planeta. Warszawa: CiS.

Żurek Wojciech. 2009. “Quantum Darwinism”. Nature Physics 5: 181-188.

\section{Streszczenie}

\section{O nowym typie monadologii}

Niniejszy artykuł rozwija pewne motywy zawarte w pracy pt. Nowa formuła monadologii (Olsztyn 2004). Próbuję dostosować monadologię do wyników nauki współczesnej. Ma to być nowy typ monadologii. Wprowadzam ideę monady jako aktywności organizującej, pojęcie monadologii nieliniowej, monadologii indeterministycznej, antymonady, makromonady i inne. Powołuję się na kwantowy darwinizm W. Żurka, ideę symbiogenezy L. Margulis, teorię chaosu deterministycznego I. Prigo- 
gine’a i teorię samoorganizacji S. Kauffmana. W nowy sposób interpretuję leibnizjańskie pojęcie „harmonii przedustanowionej”.

Słowa kluczowe: antymonada; I. Prigogine; kwantowy darwinizm; monadologia ideterministyczna; monadologia nieliniowa; nowy typ monadologii; S. Kauffman; symbiogeneza; Witkacy; W. Żurek.

\section{Abstract \\ On a New Type of Monadology}

In the article I develop some motives included in Nowa formula monadologii [New formula of monadology] (Olsztyn 2004). I try to adopt the monadology to the results of contemporary science. It is to be a new type of monadology. I introduce: a new idea of the monad as an organizing activity, a notion of non-linear monadology, a notion of non-indeterministic monadology, a notion of anti-monad, a notion of macro-monad, and others. I refer to quantum darwinism of W. Żurek, the idea of symbiogenesis of Lynn Margulis, the theory of indeterministic chaos of I. Prigogine and the theory of self-organization of S. Kauffman. I propose a new interpretation of the Leibnizian notion of "harmonia praestabilita".

Keywords: anty-monad; indeterministic monadology; I. Prigogine; new type of monadology; non-linear monadology; quantum darwinism; S. Kauffman; symbiogenesis; Witkacy; W. Żurek. 